\title{
The effect of artisanal processing methods on lysine content in selected fish species from different lakes in Uganda
}

\author{
Masette Margaret ${ }^{*}$ and Tinyiro Samuel Edgar
}

\begin{abstract}
Background: Lysine is one of the essential amino acids required in the human diet. However, it is easily lost when fish is subjected to different processing methods which may compromise the human dietary requirements.

Methods: We determined changes in lysine content of four fresh water fish species, namely Bagrus docmak, Rastrineobola argentea, Brycinus nurse and Distichodus niloticus. The fish were obtained from lakes Victoria, Kyoga, Edward and Albert in Uganda. Lysine was determined before (baseline) and after processing the four fish species using artisanal methods, namely sun-drying, salting, smoking and deep-frying.

Results: The baseline lysine content varied significantly among fish species (6.1-17.6\%). Lysine content of B. docmak from L. Victoria and Rastrineobola argentea from L. Kyoga reduced significantly by 43.2 and $55 \%$, respectively, when deep-fried. Smoking also significantly reduced lysine content in $R$. argentea by $50 \%$. Distichodus niloticus occurs in only L. Albert, and its lysine content decreased with processing method by $49.5 \%$ in deep-fried and $7.3 \%$ in sun-dried. Processing method did not significantly change lysine content of Brycinus nurse.

Conclusion: Generally, the nutritional quality with regard to lysine content of four fish species was not significantly affected by three artisanal processing methods: drying, salting and smoking. However, deep-frying significantly reduced lysine content in three species which has a bearing on public health. In this regard, awareness creation among processors and consumers about deep-fried fish products would alleviate the nutritional insecurity attributed to deep-frying. In addition, modification of the existing artisanal processing methods is necessary to avert a possible predisposition to lysine deficiency.
\end{abstract}

Keywords: Lysine, Freshwater fish, Artisanal processing, Nutritional quality

\section{Background}

Lysine is one of the eleven essential amino acids required in human diet albeit in small amounts for various physiochemical functions [29]. According to Larsen et al. [25], the composition and profile of essential amino acids determines the biological value of proteineous food. Lysine occurs in larger amounts among fishes than in terrestrial meats [30]. The lysine content of a standard protein recommended by FAO/WHO [16] is $5.8 / 100 \mathrm{~g}$ protein which underscores its importance in the human

\footnotetext{
*Correspondence: mmasette@gmail.com

Food Bio-Sciences and Agribusiness (FBA) Research Program, National Agricultural Research Laboratories (NARL), P. O. Box 7065, Kampala, Uganda
}

diet. Net protein utilization in diets is greatly affected by the content of the limiting amino acid. For instance, lysine in cereal grains is a limiting amino acid and yet cereals are major staple foods in developing economies like Uganda [21]. As such, cereals have to be supplemented with lysine-rich protein sources in order to optimize the utilization of dietary protein [49]. Carbohydrates contribute $78.6 \%$ to dietary energy consumption of Ugandan households compared to $9.7 \%$ for protein, and this is indicative of protein-deficient diets [48]. Supplementation of their carbohydrate-based diets with fish would inevitably mitigate some of these nutritional deficiencies associated with lack or inadequate consumption of proteineous foods [42]. 
Reduced dietary supply of lysine is associated with several health-related illnesses. Papes et al. [37] reported mental and physical handicap because of its important role in the synthesis of glutamate, a significant neurotransmitter in the central nervous system of mammals. Civitelli et al. [13] cited age-related bone loss, while other studies $[12,46]$ reported reduced protein turnover and induced changes in its metabolism and [43] reported increased stress-induced anxiety. Frequent consumption of fish therefore may alleviate some of these healthrelated dietary problems. However, the methods used to process or preserve fish for prolonged shelf-life storage may undermine the desired health attributes of the fishbased diets among consumers [6].

Uganda is richly endowed with water resources that include lakes, rivers dams and swamps which constitutes approximately $20 \%$ of total land surface area. The five major lakes Victoria, Kyoga, Albert, Edward, George and other water bodies provide conducive habitats for approximately 300 fish species, comprising of haplochromines $(90 \%)$ and large pelagic fishes (10\%). The major fish species of commercial importance that are exploited for export and domestic consumption include Lates niloticus (Nile perch), Oreochromis niloticus (Nile tilapia), the cat fishes Bagrus docmak and Clarias gariepinus, while the small pelagic fishes "sardine-like" include Rastrineobola argentea (Mukene), Neobola bredoi (Muziri) and Brycinus nurse (Ragoogi) [14]. The nutritional profile and composition of fish is determined by its feeding habits and food items ingested [54]. B. docmak is largely piscivorous [7], i.e. they feed on insects, crustaceans, molluscs and fish [9], while $R$. argentea and B. nurse are zooplanktivorous [50]. D. niloticus is omnivorous [23]. Regardless of the habitat, fish maintain their feeding habits although with the current climatic variability [24], some fish species have tended to have dietary shifts [31]. Owing to their feeding habits, fish protein has a higher biological value than other proteineous food sources.

The socio-economic, cultural norms, market disposition and sensory attributes desired by consumers dictate the form of processing applied to fish. Some fish species are consumed in fresh form, while others are either smoked, salted, sun-dried or fried. Smoking, in particular, is widely used as a fish preservation method in Africa largely due to its affordability and preferred sensory attributes such as taste [3, 32]. Ward [51] reported that up to $70 \%$ of the total fish catch in several communities in the third world is smoked. Most processing methods rely on lowering water activity to preserve fish. Consequently, some methods such as salting may lower the levels of amino acids due to salting out. On as is basis, dehydrated fish products have higher protein content than fresh $[19,20,39]$. Heat denatures and aggregates protein and exposes hydrophobic sites which foster new interactions that lead to a more dense protein structure [45]. On the other hand, traditional fish smoking method exposes fish to $120^{\circ} \mathrm{C}$ [15] and these elevated temperatures are known to reduce availability of lysine [10] because of its high sensitivity to intense heat [2]. The mechanism of lysine reduction entails reaction of formaldehyde from the smoke component more so, formaldehyde from smoke reacts with the s-NH group of lysine to form a complex that indirectly reduces lysine content by making it unavailable [11]. Currently, information and awareness on the effects of processing methods on the nutritional quality of fish species in Uganda are scanty and limited, respectively. The purpose of this study therefore was to determine the magnitude of lysine loss attributed to artisanal fish processing and preservation methods.

\section{Methods}

The selection criteria of fish species and preservation methods were based on market significance of species and popularity/affordability respectively. The choice of water body was dependent on availability of the fish species selected. Semutundu (Bagrus docmak) is predominantly found in lakes Edward and Victoria, while Wachone (Distichodus niloticus) and Ragoogi (Brycinus Nurse) are only found in L. Albert. Mukene (Rastrineobola argentea) is plenty in lakes Kyoga and Victoria.

Freshly caught and gutted $B$. docmak (20 pieces) was purchased at Katwe landing site $\left(0^{\circ} 08^{\prime} 35.3^{\prime \prime} \mathrm{S}\right.$, $29^{\circ} 52^{\prime} 33.0^{\prime \prime} \mathrm{E}$ ) on L. Edward and similar quantities were purchased from Wanseko landing site $\left(2^{\circ} 10^{\prime} 40.0^{\prime \prime} \mathrm{N}\right.$, $31^{\circ} 22^{\prime} 50.0^{\prime \prime} \mathrm{E}$ ) on L. Albert, from a makeshift market at the Owen Falls Dam $\left(0^{\circ} 26^{\prime} 37.7^{\prime \prime} \mathrm{N}, 33^{\circ} 11^{\prime} 04.0^{\prime \prime} \mathrm{E}\right)$ on River Nile, Jinja and Moone landing site $\left(1^{\circ} 28^{\prime} 30.8^{\prime \prime} \mathrm{N}\right.$, $\left.32^{\circ} 31^{\prime} 51.4^{\prime \prime} \mathrm{E}\right)$ on L. Kyoga. Freshly caught and gutted $D$. niloticus (20 pieces) was purchased from Wanseko landing site and $B$. nurse $(10 \mathrm{~kg})$ was purchased at Bugoigo and Walukuba landing sites on L. Albert. Freshly caught $R$. argentea $(10 \mathrm{~kg})$ was purchased from Kiyindi landing site on L. Victoria, and same quantities from Kakooge landing site on L. Kyoga.

Purchased fish samples from respective lakes were transported in insulated fish boxes to the Food Biosciences and Agribusiness Program laboratories, Kawanda, for processing into smoked, salted, sun-dried and fried products using improved artisanal methods. The large pelagic fish were scaled, beheaded, filleted and then apportioned into 300-g portions.

Preparation for smoking involved washing under running water for 2 min and then drip-drying on a small meshed rack elevated $2 \mathrm{~m}$ above the ground for $1 \mathrm{~h}$ at ambient temperature $\left(28^{\circ} \mathrm{C}\right)$. This was followed by smoking using a Chorkor kiln monitored at $60-80{ }^{\circ} \mathrm{C}$. The 
temperature was monitored using a thermocouple, ETI Therma 22 model. Mango wood (Mangifera indica) was used for smoking because it is the commonly used fuel wood in Uganda. The smoking process took $8 \mathrm{~h}$ before cooling on stainless steel tray for $1 \mathrm{~h}$ at room temperature. Samples were then coded and packaged in aluminium foil before storage in laboratory freezer, Model Electrolux made in Sweden at $-10{ }^{\circ} \mathrm{C}$ pending lysine analysis.

Preparation for salting involved washing under running water for $2 \mathrm{~min}$ and then drip-drying on a small meshed rack elevated $2 \mathrm{~m}$ above the ground for $1 \mathrm{~h}$ at ambient temperature $\left(28{ }^{\circ} \mathrm{C}\right)$. Salting was done using the ratio of $1 \mathrm{~g}$ salt to $120 \mathrm{~g}$ fish and finally spread out in the sun to dry at ambient temperatures $\left(28^{\circ} \mathrm{C}\right)$ for 2 days. The resultant salted and dried samples were sealed in polythene tubing (30 micron thickness) and kept at room temperature.

Sun-drying involved washing before drying on small meshed rack elevated $2 \mathrm{~m}$ above the ground for 3 days at approximately $28{ }^{\circ} \mathrm{C}$. Dried products were then sealed in polythene tubing ( 30 microns thick) and kept at room temperature.

Deep-frying involved washing then drip-drying for $1 \mathrm{~h}$ prior to deep-frying in a locally fabricated mild steel shallow pan containing vegetable oil-Golden fry vegetable oil (fractionated palm oil, fully refined and fortified with vitamin A) made by Bidco (U) Ltd. The oil was heated to $180{ }^{\circ} \mathrm{C}$ using gas cooker (Model IGNIS made in Brazil). The frying time was $15 \mathrm{~min}$ for all fish species. The excess oil was allowed to drain off the deep-fried samples on a stainless steel mesh tray for $1 \mathrm{~h}$ before packaging in aluminium foil and coding. Samples were then stored in a freezer at $-10{ }^{\circ} \mathrm{C}$ overnight $(12 \mathrm{~h})$.

All samples were then taken to Makerere University (MUK), Department of Chemistry laboratories, for lysine analysis. Using a blender, each sample was ground separately into powder/paste, labelled appropriately and stored under frozen conditions till ready for lysine analyses.

\section{Amino acid analysis}

The Kjedahl method [8] was used to determine total protein. A method similar to Szczêsna [40] and Stenerson [44] was used for sample preparation and amino acid analysis. Fish samples $(1 \mathrm{~g})$ were treated with per formic acid before being hydrolysed in $25 \mathrm{ml}$ of $0.1 \mathrm{M}$ HCL in a sealed tube at $110{ }^{\circ} \mathrm{C}$ for $24 \mathrm{~h}$. A $50-\mu \mathrm{L}$ aliquot of the hydrolysate containing a mix of amino acids was dried under a vacuum evaporator at $40{ }^{\circ} \mathrm{C} .100 \mu \mathrm{L}$ of the silylation reagent $\mathrm{N}$-tert-butyldimethylsilyl- $\mathrm{N}$-methyl trifluoroacetamide (MTBSTFA), followed by 100 $\mu \mathrm{L}$ of acetonitrile, was added. The mixture was heated at $100{ }^{\circ} \mathrm{C}$ for $4 \mathrm{~h}$. The sample was then neutralized with sodium bicarbonate and subjected to GC-MS analysis on a $20 \mathrm{~m} \times 0.18 \mathrm{~mm}$ I.D. $\times 0.18 \mu \mathrm{m}$ SLB $(\mathrm{tm})-5 \mathrm{~ms}$ capillary column. Amino acids were identified by comparing chromatograms and spectral data of amino acid standards with those of the sample solution.

Lysine content was expressed as g/100 g protein (\%). Lysine content of the fresh samples prior to processing was the baseline content of the respective fish species.

\section{Statistical analysis}

Data were analysed using SAS statistical software (version 9.3, 2011; SAS Institute Inc., Cary, NC, USA). Differences between lysine content means were determined by one-way ANOVA (Duncan's multiple range test) with level of significance $p<0.05$.

\section{Results}

It was observed that lysine content varied with fish species, water body and processing method. The lysine content varied according to fish species and water body (Fig. 1). Of the species investigated, B. nurse caught from L. Albert had the highest baseline lysine content (17.6\%), whereas B. docmak from L. Edward and R. argentea from Victoria had the lowest (6.1\%).

The influence of water body or habitat on lysine content has been vividly illustrated by $B$. docmak which occurs in the four lakes of Uganda. Lake Victoria B. docmak had the highest baseline lysine content $(11.1 \%)$ compared to Edward $6.1 \%$ with the lowest. The lysine content in unprocessed samples from L. Edward and L. Albert was not significantly different (Fig. 2).

\section{Effect of processing/preservation methods on lysine}

The processing method applied to preserve fish affected lysine content differently. An example is explicitly shown by D. niloticus which occurs in L. Albert only (Fig. 3).

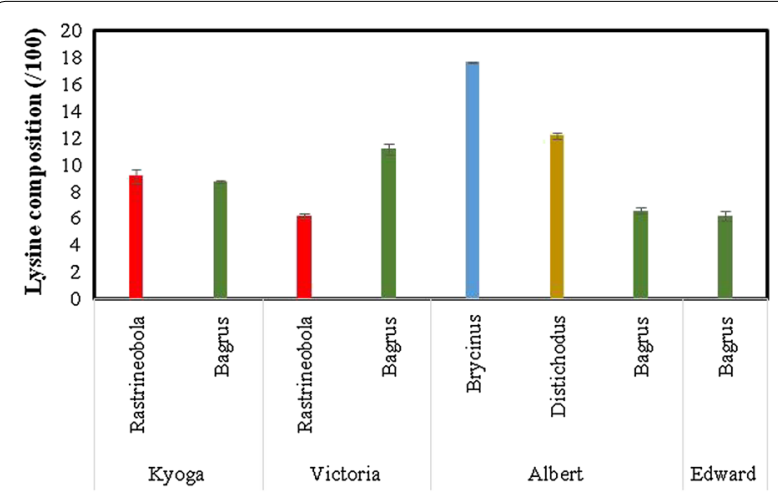

Fig. 1 Mean lysine content variation among fish species (unprocessed) and water bodies 


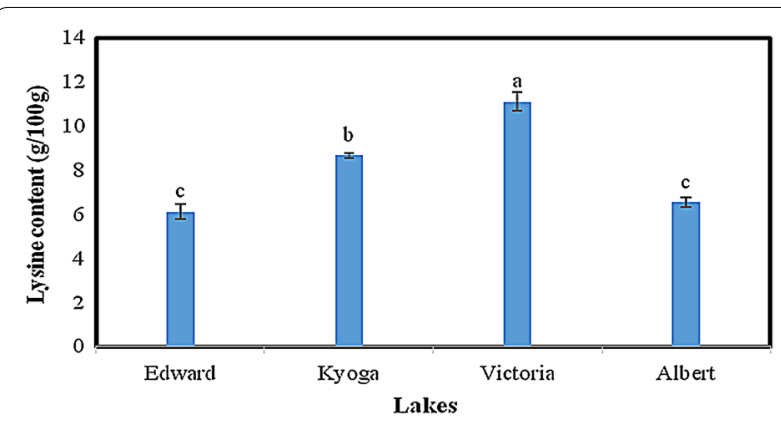

Fig. 2 Effect of habitat (lakes) on lysine content in unprocessed fresh Bagrus fish species

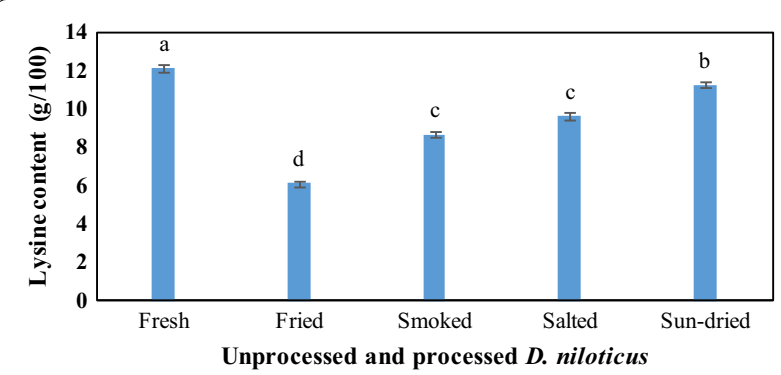

Fig. 3 Effect of preservation method on lysine content in $L$ Albert $D$. niloticus

Essentially, all preservation methods caused a decline in the lysine content and the magnitude of loss varied with the method. The deep-frying method caused a lysine loss of 49.5\%; smoking 28.4\%; salting 20.7\%; and sun-drying only $7.3 \%$. The effect trend of decrease or increase in lysine in all fish species from the four lakes subjected to the four processing methods is shown in Fig. 4.

Deep-frying did not have significant effect on lysine in $B$. nurse but significantly decreased the lysine content of L. Albert $D$. niloticus, L. Kyoga $R$. argentea and L. Victoria $B$. docmak $(p<0.05)$. The decrease in lysine for $\mathrm{L}$. Edward and L. Kyoga B. docmak was insignificant. However, deep-frying resulted in an insignificant increase in lysine content of L. Victoria $R$. argentea and L. Albert fishes (B. nurse and B. docmak).

Smoking insignificantly increased lysine content of L. Albert and L. Edward B. docmak and L. Victoria $R$. argentea. However, its content decreased in L. Albert D. niloticus, L. Victoria and L. Kyoga B. docmak, and L. Kyoga $R$. argentea. Smoked B. nurse retained its lysine content as the unprocessed fresh sample. Lysine retention in smoked $B$. nurse was similar to its deep-fried version. However, these two methods contributed to the decrease in lysine in L. Kyoga $R$. argentea. The decrease

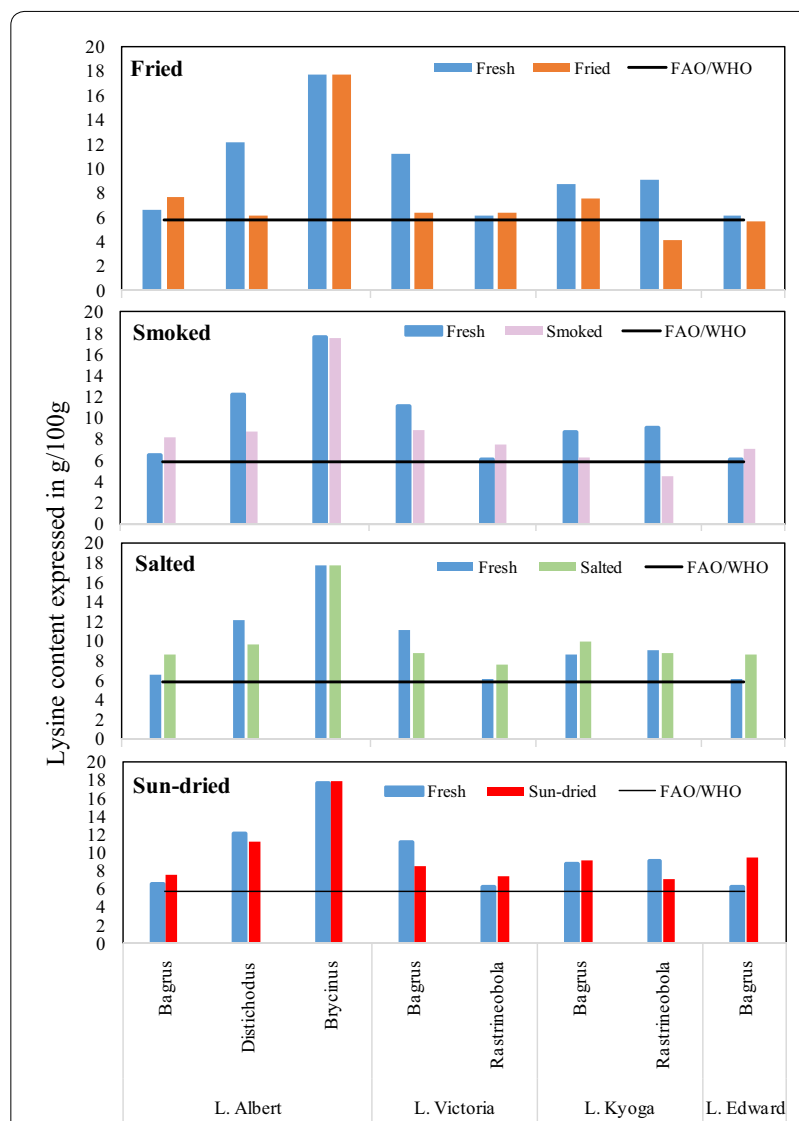

Fig. 4 Effect of processing methods on lysine content in four different fish species inhabiting four different lakes in Uganda compared to recommended $\mathrm{FAO} / \mathrm{WHO}$ value

was not detected in the same species inhabiting $\mathrm{L}$. Victoria.

On the other hand, salting decreased the lysine content of L. Albert D. niloticus, L. Victoria B. docmak and L. Kyoga $R$. argentea. On the contrary, it increased lysine content of L. Victoria $R$. argentea and $B$. docmak inhabiting L. Albert, L. Kyoga and L. Edward. Salting did not have significant effect on lysine content of $B$. nurse.

Although the increase in lysine content of sun-dried L. Edward B. docmak was significant, it the was not significant in B. docmak occurring in L. Albert and L. Kyoga, $B$. nurse in L. Albert and in L. Victoria R. argentea. Sun-drying decreased lysine content of L. Albert $D$. niloticus, L. Victoria B. docmak and L. Kyoga R. argentea. Sun-drying had the least effect on lysine content. Of the fish species peculiar to L. Albert, the small pelagic fish $B$. nurse had significantly higher baseline lysine content and processing did not significantly vary this. Generally, all processing methods reduced lysine content in $D$. niloticus, but deep-frying had a significant reduction of $50 \%$. 


\section{Discussion}

Amino acids and particularly lysine play a vital role in physiochemical functions of the human body [29]. However, several studies have reported losses due to processing methods $[10,11]$. Most artisanal fish processing methods in Uganda preserve products by dehydration and inevitably affect the nutritional quality of the resultant products.

Our findings indicated that lysine content changed with processing methods. However, it largely complied with the recommended $\mathrm{FAO} / \mathrm{WHO}$ lysine value for a standard protein of 5.8/100 g protein for most methods. As such, modification may not be required as precautionary measure to ensure the prevailing market and cultural demands in Uganda. Nevertheless, in incidences where a method led to lysine loss, respective methods may have to be modified to maintain nutritional quality. For example, deep-frying contributed to the loss of lysine by almost 50\% in both species: $R$. argentea and D. niloticus. This is a nutritional drawback in the $R$. argentea fishery because the fried products had gained popularity among a cross section of consumers although deep-frying is a recent development in Uganda.

Due to its effect on lysine, deep-frying should be modified to achieve the desired balance of sensory and nutritional attributes. Modification may entail change in processing conditions from the current $180^{\circ} \mathrm{C}$ to probably less than $60^{\circ} \mathrm{C}$ and exposure time of less than $15 \mathrm{~min}$. According to [53], losses in amino acid content including lysine during frying can be mitigated by limiting the frying time to about $2 \mathrm{~min}$. However, consumers in Uganda prefer well-done and crispy fish products that inevitably require at least $15 \mathrm{~min}$, so supplementation of their diets with lysine-rich alternative foods may be a more appropriate option than limiting frying time [27].

The lysine loss observed in $R$. argentea, D. niloticus and $B$. docmak is corroborated by other studies. Garcia-arias et al. [19] reported that some amino acids such as lysine may be lost in heat-processed fish samples due to the formation of different Maillard products. Lysine is particularly susceptible to Maillard reaction owing to a free amino group at the epsilon carbon that readily reacts with reducing sugars [47]. Similar results were obtained in a study on four marine fishes in Nigeria Oluwaniyi et al. [33]. They reported a reduction in total amino acid content of Clupea harengus, Scomber scombrus, Trachurus trachurus and Urophycis tenuis when fried in palm oil. Further lysine reduction attributed to the development of heterocyclic aromatic amines as a consequence of frying was reported by Oz et al. [35]. The frying enhances the formation of a hard surface crust which tends to interfere with amino acid analysis by limiting hydrolysis of fish protein $[18,52]$.
Smoking also had similar effects on lysine in $R$. argentea like deep-frying although not to the same magnitude of $50 \%$ loss. This finding corroborated with several other previous studies $[2,4,11]$. Consumption of smoked $R$. argentea in urban centres of Uganda is on the increase, and therefore lysine loss will have nutritional consequences unless mitigation measures are put in place. The elevated temperatures applied to fish during smoking in Uganda have the potential to cause lysine loss because according to [4], lysine losses increased with temperature from $6 \%$ at $25{ }^{\circ} \mathrm{C}$ to $56 \%$ at $40{ }^{\circ} \mathrm{C}$. Considering that the smoking temperature in Uganda may exceed $120{ }^{\circ} \mathrm{C}$, the likelihood of lysine loss may surpass the $80 \%$ mark which may be nutritionally deficient for the consumers of smoked fish products. The use of liquid smoke [28] may be a viable mitigation measure, but its expense and availability may render it an implausible option. The effect of smoking on lysine is not only limited to fish species, but it has similar effects in other aquatic resources. When tiger shrimp (Penaeus monodon) was hot smoked, lysine content reduced substantially due to Maillard reaction [5].

Contrary to the previous studies that reported loss of lysine as a result of smoking $[2,4,11]$, the findings of the present study indicated an increase in some species like B. docmak, D. niloticus and B. nurse. This may be gratifying to consumers of smoked fish products in Uganda because $B$. docmak is always smoked. D. niloticus and $B$. nurse, on the other hand, are rarely smoked. Other studies $[6,17]$ corroborated these findings whereby the lysine content of the African mud catfish (C. gariepinus) smoked at $60-70{ }^{\circ} \mathrm{C}$ for $24 \mathrm{~h}$ increased by at least $5 \%$. This was attributed to moisture loss that led to concentration of the protein after smoke drying. In another study on protein quality of fish products under various processing treatment, it was reported that smoked products had greater essential amino acid content (7.66-9.7\%) with lysine and leucine being predominant [49].

Generally, sun-drying did not reduce the lysine content beyond the FAO/WHO recommended value. Probably this was due to low ambient drying temperatures of $28^{\circ} \mathrm{C}$. Essentially, the lysine content in $B$. nurse seemed to be unaffected by any of the processing methods. B. nurse has a high fat content $\geq 15 \%$ [27]. It is probable that fat bound to the protein protected it from degradation and thus lysine loss. Traditionally, B. nurse is sun-dried and used as protein source for animal feed manufacture in Uganda hence its lysine is made available to humans through secondary sources like chicken and pork. Sundrying significantly increased lysine content of $B$. docmak (L. Edward); therefore, this provides a nutritionally viable alternative processing method for the fisher folk in addition to the more commonly used smoking. However, 
from culinary viewpoint, sun-dried whole $B$. docmak is rarely consumed by the majority of Ugandan fish consumers. The only viable option may be transformation into powdered products which has wide application among regular fish consumers in Uganda [26].

Apart from processing methods, the lysine content varied significantly with fish species. The mean baseline lysine content of the four fish species investigated in this study met the minimum requirement for a standard protein in human diet pegged at $5.8 \mathrm{~g} / 100 \mathrm{~g}$ [16]. This may be attributed to the physiological disposition of the species and feed conversion rates [36]. It was similar to two other fresh water species Clarius gariepinus and Tilapia zillii which were reported as 10.64 and $10.37 \%$, respectively [34]. Abdullahi [1] also reported lysine variation in Chrysichthys nigrodigitatus, Barus filamentous and Auchenoglanis occidentals. Lysine variation due to species is corroborated with other studies $[24,38,41,54]$.

\section{Conclusion}

Generally, lysine content varied with fish species before and after processing. Deep-frying significantly reduced lysine content in three of the four fish species, and therefore the artisanal method currently in use should be modified or avoided for health reasons and nutritional quality. None of the four processing methods affected the lysine content of $B$. nurse for reasons that may require further research to decipher. Further studies should also be conducted to ascertain appropriate deep-frying temperatures and exposure time for fish. New policies should target increasing public health awareness of consumers and processors regarding the nutritional quality losses associated with deep-frying as a fish processing method as well as encouraging supplementation with other lysine-rich foods where it is used.

\section{Abbreviations}

FBA: Food Bioscience and Agri-business; FAO: Food and Agriculture Organization of the United Nations; GC-MS: Gas Chromatography-Mass Spectrophotometry; MUK: Makerere University, Kampala; WHO: World Health organization.

\section{Authors' contributions}

MM designed the project proposal for funding, designed the sampling plan and processing protocols, made arrangement with laboratory technicians, supervised analysis, drafted and reviewed the manuscript prior to submission. TSE collected samples from landing sites and processed them according to predetermined protocols, labelled samples for delivery to analytical laboratories, performed the statistical analysis of collected and reviewed first and second draft of the manuscript. Both authors read and approved the final manuscript.

\section{Authors' information}

MM is a Senior Research Officer and Program Leader of Food Bioscience and Agri-business (FBA); one of the five Programs under National Agricultural Research Laboratories (NARL). She has over 30 years of working experience as a researcher, supervisor, lecturer and extension worker in Uganda's Fisheries Sub-sector. TSE, on the other hand, is a Research Officer under FBA with a Master's degree in Food Science and BSc in Food Science and Technology. The two authors have been working together for the last five years and published several papers in other peer reviewed journals.

\section{Acknowledgements}

Authors wish to acknowledge FAO of the United Nations for funding this study. Fisher folk at study landing sites along lakes Victoria, Albert, Kyoga and Edward are also thanked for supplying high-quality raw material samples for various processing methods. Finally, technicians at Chemistry Department, Makerere University, are acknowledged for their input.

\section{Competing interests}

The authors declare that they have no competing interests with regard to this manuscript.

\section{Availability of supporting data}

The raw data sets will be made available to anyone if a formal request is made to the corresponding author in writing.

\section{Consent for publication}

Not applicable because the manuscript does not include details, images or videos relating to individual participants.

Ethical approval and consent to participate None applicable.

Funding

FAO funded this study as highlighted in acknowledgement section.

Received: 9 March 2016 Accepted: 27 October 2016

Published online: 08 November 2016

\section{References}

1. Abdullahi SA. Investigation on nutritional status of Chrysicthys nigrodigitatus, Barus filamentous and Aucheoglanis occidentalis (Family: Bagridae). J Arid Zone Fish. 2001;1:39-50.

2. Adebowale BA, Dongo LN, Jayeola CO, Orisajo SB. Comparative quality assessment of fish (Clarias gariepinus) smoked with cocoa pod husk and three other different smoking materials. J Food Technol. 2008;6(1):5-8.

3. Adeyemi OT, Osilesi OO, Onajobi F, Adebawo O, Afolayan AJ. Stability study of smoked fish, horse mackerel (Trachurus trachurus) by different methods and storage at room temperature. Afr J Biochem Res. 2013;7(6):98-106

4. Akande GR, Oladosu OH, Tobor JG. A comparative technical and economic appraisal of fish smoking: two traditional ovens and a new Improved Magbon-Alade oven. FAO Fisheries Report (FAO). 1998.

5. Akintola SL, Brown A, Bakare A, Osowo OD, Omolola B. Effects of hot smoking and sun drying processes on nutritional composition of giant tiger shrimp (Penaeus monodon, Fabricius, 1798). Polish J Food Nutr Sci. 2013;63(4):227-37.

6. Akinwumi FO. Effects of smoking and freezing on the nutritive value of African Mud. Catfish, Clarias gariepinus Burchell, 1822. J Agric Sci. 2014; 6(11), 143-5.

7. Anja H, Mengistou S. Food and feeding habits of the catfish, Bagrus docmak (Forsskal, 1775) (Pisces: Bagridae) in Lake Chamo, Ethiopia. SINET: Ethiopian J Sci. 2004;24(2):239-54.

8. AOAC. Official methods of analysis of the Association of Official Analytical Chemists. 15th ed. Washington, DC: Association of Official Analytical Chemists; 1990.

9. Bailey RG. Guide to the fishes of the River Nile in the Republic of the Sudan. J Nat Hist. 1994;28:937-70.

10. Bhuiyan AKMA, Ackman RG, Lall SP. Effects of smoking on protein quality of Atlantic Mackerel (Scomber scombrus). J Food Process Preserv. 1986;10:115-26. doi:10.1111/j.1745-4549.1986.tb00011.x.

11. Carton I, Bocker U, Ofstad R, Sørheim O, Kohler A. Monitoring secondary structural changes in salted and smoked salmon muscle myofiber proteins by FT-IR microspectroscopy. J Agric Food Chem. 2009;57(9):3563-70. 
12. Chang YM, Wei HW. The effects of dietary lysine deficiency on muscle protein turnover in post weanling pigs. Asian-Aust J Anim Sci. 2005;18(9):1326-35.

13. Civitelli R, Villareal DT, Agnusdei D, Nardi P, Avioli LV, Gennari C. Dietary L-lysine and calcium metabolism in humans. Nutrition (Burbank, Los Angeles County, Calif.). 1991;8(6), 400-5.

14. Ministry of Agriculture Animal Industry and Fisheries (MAAIF)—Department of Fisheries Resources (DFR), 2012. Annual Report 2010/2011. Uganda.

15. Eyo AA. Fish processing technology in the tropics. National Institute for Freshwater Fisheries Research, New Bussa, Nigeria, ISBN-13: 9781770457 , pp. 403. 2001

16. FAO/WHO. Protein quality evaluation. Report of the Joint FAO/WHO expert consultation. FAO Food and Nutrition Paper 51, Food and Agriculture Organization of the United Nations, Rome, Italy. 1991.

17. Fapohunda OO, Ogunkoya M. Effect of smoke-drying on the proximate composition of Tilapia zillii, Parachanna obscura and Clarias gariepinus obtained from Akure, Ondo-State, Nigeria. Animal Res Int. 2008; 3(2), $478-80$.

18. Fillion L, Henry C. Nutrient losses and gains during frying: a review. Int J Food Sci Nutr. 1998;49(1):157-68.

19. Garcia Arias MT, Alvarez-Pontes E, Garcia-Linares MC, Garsia-Fernandez MC, Sanchez FJ. Cooking-freezing-reheating (CFR) of sardine (Sardina pilchardus) fillets. Effect of different cooking and reheating procedures on the proximate and fatty acid compositions. Food Chem. 2003;83(3):349-56.

20. Gokoglu N, Yerlikaya P, Cengiz E. Effect of cooking methods on the proximate composition and mineral contents of rainbow trout (Oncorhynchus mykiss). J Food Chem. 2004;84(1):19-22.

21. Gómez-Galera S, Rojas E, Sudhakar D, Zhu C, Pelacho AM, Capell T, Christou P. Critical evaluation of strategies for mineral fortification of staple food crops. Transgenic Res. 2010;19(2):165-80.

22. Hecky RE, Mugidde R, Ramlal PS, Talbot MR, Kling GW. Multiple stressors cause rapid ecosystem change in Lake Victoria. Freshw Biol. 2010;55(s1):19-42.

23. Hickley P, Bailey RG. Food and feeding relationships of fish in the Sudd swamps (River Nile, southern Sudan). J Fish Biol. 1987;30(2):147-59.

24. Huss HH. Quality and quality changes in fresh fish. FAO fisheries technical paper. p. 348. 1995.

25. Larsen R, Stormo SK, Dragnes BT, Elvevoll EO. Losses of taurine, creatine, glycine and alanine from cod (Gadus morhua L.) fillet during processing. J Food Compos Anal. 2007:20(5):396-402.

26. Masette M. Akullo D. \& Nakawoza L. Transformation of up-stream products into fish powders for enrichment of school meals in Uganda. FAO Technical Report. 2016.

27. Masette, M. Inland small pelagic fisheries utilisation options, marketing and opportunities for support. Smart Fish Report. 2012.

28. Masette M. Liquid smoke treatment as an alternative method to traditional smoking in fish processing. CNAA M. Phil. Thesis. 1990.

29. Miller ER, Ullrey DE. The pig as a model for human nutrition. Annu Rev Nutr. 1987;7(1):361-82.

30. Nahid MN, Latifa GA, Farid FB, Begum M. Evaluation of biochemical composition of salt and garlic treated smoke-dried Chapila (Gudusia chapra Hamilton, 1822) and Kaika (Xenentodon cancila Hamilton-Buchanan, 1822) Fish at Laboratory Condition $\left(27-31^{\circ} \mathrm{C}\right)$. Res. J. Animal, Veterinary and Fishery Sci. 2014; 2(10), 10-15.

31. Njiru M, Okeyo-Owuor JB, Muchiri M, Cowx IG. Shifts in the food of Nile tilapia, Oreochromis niloticus (L.) in Lake Victoria, Kenya. Afr J Ecol. 2004;42(3):163-70.

32. Nyarko HD, Obodai EA, Coomson LK, Coomson SS, Aniwe Y. Microbial profile of smoked sardine (Sardilella aurita) AT smoking sites and market centres of Tema, Ghana-1. Arch Appl Sci Res. 2011;3(3):443-53.
33. Oluwaniyi O, Dosumu O, Awolola G. Effect of local processing methods (boiling, frying and roasting) on the amino acid composition of four marine fishes commonly consumed in Nigeria. Food Chem. 2010; 123(4):1000-6.

34. Osibona AO, Kusemiju K, Akande GR. Fatty Acid Composition and Amino Acid Profile of Two Freshwater Species, African Catfish (Clarias gariepinus) and Tilapia (Tilapia zillii). Afr J Food Agric Nutr Dev. 2009;9(1):608-21.

35. Oz F, Kaban G, Kaya M. Effects of cooking methods on the formation of heterocyclic aromatic amines of two different species trout. Food Chem. 2007; 104:67-72.

36. Pandian TJ, Raghuraman R. Effects of feeding rate on conversion efficiency and chemical composition of the fish Tilapia mossambica. Mar Biol. 1972;12(2):129-36.

37. Papes F, Surpili JS, Langone F, Trigo JR, Arruda P. The essential amino acid lysine acts as precursor of glutamate in the mammalian central nervous system. FEBS Lett. 2001; 488, 34-8.

38. Potter NN, Hotchkiss JH. Food science, 5th edn. 1995.

39. Saldana T, Benassi MT, Bragagnolo N. Fatty acid contents evolution and cholesterol oxides formation in Brazilian sardines (Sardinella brasiliensis) as a result of frozen storage followed by grilling. J Food Sci Technol. 2007. doi: 10.1016/..lwl.2007.08.023.

40. Szczêsna T. Protein content and amino acid composition of bee-collected pollen from selected botanical origins. J Agric Sci. 2006;50(2):81-90.

41. Sikorski ZE, Kolakowska A, Pan BS. The nutritive composition of the major groups of marine food organisms. In Sikorski ZE (ed) Seafood: resource, nutritional composition, and preservation. New York: CRC Press, Inc.; 1990. p. 30-45.

42. Silva BO, Adetunde OT, Oluseyi TO, Olayinka KO, Alo BI. Effects of the methods of smoking on the levels of polycyclic aromatic hydrocarbons (PAHs) in some locally consumed fishes in Nigeria. Afr J Food Sci. 2011; 5(7), 384-91.

43. Smriga M, Kameishi M, Uneyama H, Torii K. Dietary L-lysine deficiency increases stress-induced anxiety and fecal excretion in rats. J Nut. 2002:132(12):3744-6.

44. Stenerson KK. The derivatization and analysis of amino acids by GC-MS. Sigma-Aldrich. Reporter US Volume 25.3. 2011.

45. Straadt IK, Rasmussen M, Anderson HJ, Bertram HC. Aging-induced changes in microstructure and water distribution in fresh and cooked pork in relation to water-holding capacity and cooking loss-a combined confocal laser scanning microscopy (CLSM) and low-field nuclear magnetic resonance relaxation study. J Meat Sci. 2007; 75: 687-95.

46. Tesseraud S, Peresson R, Lopes J, Chagneau AM. Dietary lysine deficiency greatly affects muscle and liver protein turnover in growing chickens. $\mathrm{Br} J$ Nutr. 1996;75(06):853-65.

47. Thorpe SR, Baynes JW. Maillard reaction products in tissue proteins: new products and new perspectives. Amino Acids. 2003;25(3):275-81.

48. Uganda Bureau of Statistics. Uganda National Household Survey 2005/2006. 2007

49. Usydus Z, Szlinder-Richert J, Adamczyk M. Protein quality and amino acid profiles of fish products available in Poland. Food Chem. 2009; 112; 139-45.

50. Wanink JH, Witte F. Rapid morphological changes following niche shift in the zooplanktivorous cyprinid Rastrineobola argentea from Lake Victoria. Netherlands J Zool. 2000; 50(3), 365-72.

51. Ward AR. Fish smoking in the tropics. A review. Tropical Sci. 1995:35:103-12.

52. YuTH, Wu CM, Ho CT. Volatile compounds of deep-oil fried, microwaveheated and oven-baked garlic slices. J Agric Food Chem. 1993; 41:800-05.

53. Zhang $Y$, Wang $X$, Wang $W$, Zhang J. Effect of boiling and frying on nutritional value and in vitro digestibility of rabbit meat. Afr J Food Sci. 2014:8(2):92-103.

54. Zenebe T, Ahigren G, Boberg M. Fatty acid content of some freshwater fish commercial importance from tropical lakes in the Ethiopian rift valley. J Fish Biol. 1998; 53: 987-1005. 